\title{
PENGARUH TIPOGRAFI PADA ERA MASSIMO VIGNELLI TERHADAP TIPOGRAFI MICHAEL BIERUT
}

\author{
Irwan Harnoko; Dria Setiautami \\ Jurusan Desain Komunikasi Visual, School of Design, BINUS University \\ Jln. K.H. Syahdan No. 9, Palmerah, Jakarta Barat 11480 \\ irwanonni@yahoo.com; driasetiautami@yahoo.com
}

\begin{abstract}
Massimo Vignelli is a senior graphic designer lived in New York, as a vocal modernism against postmodernism. His statement firmly opposing post-modernism in several occasions: interview in Helvetica the movie, typeradio, talkshow, and some articles in Looking Closer or AIGA Journal. Graphic design works of Massimo Vignelli reflected his characteristic, which is firmly choosing typeface. Typefaces of Vignelly are around 5 typefaces: Bodoni, Helvetica, Times Roman, Century, and Futura. The article uses formal analysis method. The writers collected materials about Michael Bierut, Massimo VIgnelli and Tibor Kalman from books and websites. The writers compare the typeface opinion of Massimo Vignelli (modernism designer), Michael Bierut designer (transition era designer from modernism to post-modernism), and Tibor Kalman (a designer in A Century of Graphic Design, as the influencer of Bierut's betrayal over Vignelli).
\end{abstract}

Keywords: Vignelli, Bierut, graphic design, modernism, post-modernism

\begin{abstract}
ABSTRAK
Massimo Vignelli adalah seorang desainer grafis senior yang bertempat tinggal di New York beraliran modernisme yang sangat vokal melawan arus posmodernisme. Pernyataannya sangat keras menentang posmodernisme baik saat wawancara yang dimuat dalam film Helvetica, typeradio, talkshow dan beberapa tulisan yang dimuat seperti dalam Looking Closer maupun AIGA journal. Karya desain grafis Massimo Vignelli sangatlah mencerminkan kepribadiannya, salah satu sikap teguhnya adalah dalam pemilihan typeface. Typeface yang Vignelli gunakan adalah seputar dari 5 typeface: Bodoni, Helvetica, Times Roman, Century, Futura. Penulisan artikel ini menggunakan metode analisa formal. Penulis mengumpulkan bahan-bahan mengenai Michael Bierut, Massimo Vignelli dan Tibor Kalman dari buku dan internet. Penulis membuat perbandingan untuk antara pendapat Massimo Vignelli (desainer aliran modernisme) dengan desainer Michael Bierut (desainer yang mengalami masa peralihan dari modernisme hingga postmodernisme) dan Tibor Kalman (seorang desainer dalam buku A century of graphic design).
\end{abstract}

Kata kunci: Vignelli, desain grafis, modernisme, pasca modernisme 


\section{PENDAHULUAN}

Massimo Vignelli lahir di Italia pada tahin 1931. Dia adalah seorang desainer yang bekerja pada bermacam-macam area desain. Mulai dari kemasan, furniture, showroom, signage public yang semuanya tergarap dalam Vignelli Asociates. (Vignelli Associates dan Vignelli design didirikan tahun1971). Perusahaan ini bertempat di New York yang saat pertama didirikan bersama istrinya: Lela Vignelli bertempat di Milan.

Massimo Vignelli pernah berkata "Bila kamu bisa membuat satu desain, maka kamu bisa membuat semua desain" dan hal tersebut tercermin dari karya-karya desainnya yang beragam. Vignelli bekerja sepenuh hati dalam tradisi Modernis, dan berfokus pada kesederhanaan (minimalis) melalui penggunaan bentuk geometris dasar dalam semua karyanya.

Massimo Vignelli pada masa remajanya sangat terpesona dengan desain dan banyak bergaul dengan arsitek besar pada jamannya. (Vignelli merasa masa mudanya penuh dihabiskan dalam komunitas arsitektur) Oleh karena itu tak heran bila dia melanjutkan sekolah di the Politecnico di Milano dan akhirnya di the Università di Architettura, Venice. Pada tahun 1966 Vignelli membuat perusahaan Unimark International di Amerika, dan dengan cepatnya perusahaan tersebut menjadi salah satu perusahaan desain terbesar di dunia. Banyak perusahaan besar yang telah digarap identitas visualnya oleh Unimark Internasional: American Airlines, ikon sistem dan desain peta New York City Subway.

Desain interior, environmental design, desain kemasan, desain grafis, desain furniture, dan desain produk, semua bidang tersebut dikerjakan oleh Massimo Vignelli. Kliennya di Vignelli Associates adalah perusahaan besar seperti IBM, Knoll, Bloomingdale dan American Airlines. Vignelli berpartisipasi dalam visi proyek Bursa Efek pada tahun 2007, serta penerbitan buku, Vignelli: Dari A sampai Z, yang berisi serangkaian esai yang menggambarkan prinsip-prinsip dan konsep di balik all good design (semua desain yang baik). Hal ini berdasarkan abjad disusun berdasarkan topik, kira-kira mendekati program seperti yang telah dia ajarkan di Harvard School of Desain dan Arsitektur.

Pada Januari 2009, Vignelli merilis Canon Vignelli sebagai e-book gratis. Versi yang diperluas dicetak pada bulan September 2010, tetapi yang asli tetap tersedia untuk di-unduh di situs Associates Vignelli. Dalam pendahuluan Vignelli menulis, "Saya berpikir bahwa itu mungkin berguna untuk menempuh/melalui beberapa lingkup pengetahuan profesional saya, dengan harapan meningkatkan kemampuan desain mereka [desainer muda]. Kreativitas perlu didukung oleh pengetahuan untuk dapat melakukan yang terbaik.”

Massimo dan Lella Vignelli menyumbangkan seluruh arsip karya desain mereka pada tahun 2008 untuk Rochester Institute of Technology, dekat Rochester, New York. Arsip tersebut dipamerkan di gedung baru bulan September 2010 yang dirancang oleh Lella dan Massimo Vignelli, dikenal sebagai The Vignelli Center for Design Studies. termasuk di antara menawarkan banyak ruang pameran, ruang kelas, dan kantor.

“The Vignelli Center for Design Studies (TVC) akan menjadi tempat arsip komprehensif kami untuk desain grafis, furnitur dan benda-benda lainnya" kata Vignelli. Di bawah arahan R. Roger Remington (the Vignelli Distinguished Professor of Design at RIT), hal tersebut akan mendorong studi yang berhubungan dengan desain Modernis dengan program dan pameran pada pekerjaan TVC serta mata pelajaran terkait lainnya. TVC menjadi yang pertama bila dilihat dari jenis dan ukuran besarnya , The Vignelli Center akan menjadikan posisi RIT pada garis depan internasional studi desain. Itulah salah satu mimpi dari Vignelli dan Lela yang terwujudkan. 


\section{METODE}

Penulisan artikel ini menggunakan metode analisa formal. Penulis mengumpulkan bahanbahan mengenai Michael Bierut (2007) khususnya, Massimo Vignelli (2006) dan Tibor Kalman (dalam Aynsley, 2001) dari buku dan internet. Penulis membuat perbandingan untuk antara pendapat Massimo Vignelli (desainer aliran modernisme) dengan desainer Michael Bierut (desainer yang mengalami masa peralihan dari modernisme hingga postmodernisme) dan Tibor Kalman (seorang desainer dalam buku A century of graphic design), yang dikelompokan dalam desainer digital era bersama Émigré, April Greiman, Cranbrook Academy of Art, Erik Spiekermann, David Carson. Namun penulis tetap memasukannya dalam kelompok postmodernisme sesuai pemikiran Massimo Vignelli yang menyamaratakan kelompok itu adalah segerombolan penyakit musuh modernism).

\section{Vignelli (1991) menuliskan:}

Saya dibesarkan untuk percaya bahwa seorang arsitek harus mampu merancang segala sesuatu dari sendok hingga kota. Pada akar keyakinan ini adalah komitmen untuk memperbaiki desain dari segala sesuatu yang dapat dibuat untuk membuatnya lebih baik. Untuk membuatnya lebih baik tidak hanya dari sudut pandang fungsional atau mekanis, tetapi untuk merancang untuk mencerminkan nilai-nilai budaya dan etika, integritas etis. Integritas tujuan, bahan, dan proses manufaktur.

Integritas tujuan menyiratkan analisis dari apa masalahnya. Artinya, kemungkinan apa untuk berbagai solusi: solusi yang harus disaring untuk menentukan yang paling tepat untuk problem tersebut. Bukan hanya alternatif yang mungkin saya suka, tapi satu yang menjawab semua pertanyaan yang diajukan oleh masalah. Solusi untuk masalah dalam masalah itu sendiri. Untuk mengatasi semua pertanyaan yang diajukan oleh masalah, bagaimanapun, adalah tidak cukup. Solusi harus mencerminkan pendekatan yang diambil, dan berdasarkan konfigurasi, merangsang reaksi budaya yang melihat (audiens), bukan menggelitik secara emosional. Dalam proses ini, tidak ada taken for granted (menerima begitu saja), tidak ada dogma (keyakinan terhadap sesuatu yang tidak boleh dirubah oleh adanya akal rasio atau pendapat/ide-ide manusia), tidak ada ide yang terbentuk sebelumnya diasumsikan atau diadopsi tanpa mempertanyakan mereka dalam konteks proyek.

Saya dibesarkan untuk percaya bahwa, sebagai seorang desainer, saya memiliki tanggung jawab untuk memperbaiki dunia di sekitar kita, untuk membuatnya menjadi tempat yang lebih baik untuk hidup, untuk memerangi dan melawan hal-hal sepele, kitsch (seni ada semata-mata untuk sarana hiburan belaka), dan segala bentuk subkultur yang visual mencemari dunia kita . Etika Modernisme, atau saya harus mengatakan ideologi Modernisme, merupakan ideologi melawan, pertempuran yang sedang berlangsung untuk memerangi semua kesalahan yang dikembangkan oleh industrialisasi selama abad terakhir. Modernisme adalah komitmen terhadap keserakahan, komersialisasi, eksploitasi, vulgarisasi, murahan. Modernisme dari dahulu dan selalu mencari kebenaran, mencari integritas, mencari stimulasi budaya dan memperkaya pikiran. Modernisme bukan gaya (style), tapi sikap. Hal ini sering disalahpahami oleh orang-orang desainer yang memikirkan kebangunan rohani dari bentuk (form) bukan pada isi (konten) dari Modernisme. Sejak awal, Modernisme memiliki urgensi utopianisme: untuk membuat dunia lebih baik dengan desain. Hari ini kita tahu lebih baik. Dibutuhkan lebih dari desain untuk mengubah keadaan. Namun tujuan budaya kepercayaan Modernis masih berlaku, karena kita masih memiliki terlalu banyak sampah di sekitar kita, tidak hanya sampah material, tetapi sampah intelektual juga. Dalam hal itu, saya nilai, mendukung, dan mempromosikan relevansi lanjutan dari gerakan modern sebagai arus utama budaya abad kita.

Peristiwa budaya dua puluh tahun terakhir telah memperluas dan memperdalam isu dan nilai yang dipromosikan oleh gerakan modern. Revisi dari banyak masalah Modernis telah memperkaya persepsi kita dan telah memberikan kontribusi untuk meningkatkan kualitas pekerjaan. Peningkatan jumlah arsitek dan desainer dengan pelatihan yang baik memiliki efek positif pada Masyarakat kita dan lingkungan kita. Banyak yang masih harus dilakukan untuk meyakinkan industri dan pemerintah bahwa desain merupakan bagian integral dari proses produksi dan bukan hiasan pada menit-menit terakhir. 
Energi budaya dari gerakan modern masih menyala, mengisi bahan bakar intelektualitas melawan tren murahan, nilai-nilai temporer (sementara), titillations (godaan) dangkal yang diajukan oleh media, yang keberadaannya tergantung pada sesuatu yang tdk kekal. Banyak dari mode saat diciptakan, didukung, dan dibuang oleh media yang sangat menghasilkan perubahan itu dan agenda untuk bertahan hidup. Ini adalah lingkaran setan. Ini selalu ada, hanya saja sekarang lebih besar dari sebelumnya.

Seperti yang terlihat dalam perspektif historis yang luas, Pertapa Modernisme, spartan (orang yang tabah) terlihat masih memiliki posisi yang menjulang tinggi terhadap kekuatan dan gagasan yang melekat pada martabat Modernisme terhadap nilai-nilai abadi sebagai lawan nilai nilai temporer dan hal itu masih sangat menarik untuk menjadi intelektual saya. Para arsitek terbaik di dunia saat ini semua Modernis pada intinya, dan begitu juga desainer terbaik. Para pengikut mode Post-modernis hilang, dikurangi menjadi karikatur dari masa lalu. Post-modernisme harus dianggap yang terbaik sebagai evaluasi kritis dari masalah Modernisme. Dalam perspektif itu, telah sangat membantu untuk memperbaiki, memperluas, memperbaiki masalah Modernisme. Tak satu pun dari kita akan sama tanpa itu. Namun, kurangnya ideologi yang mendalam akhirnya membawa Post-modernisme ke tahap terminal. Dalam kebingungan budaya yang disediakan oleh pluralisme dan manifestasi eklektik nya, Modernisme yang menemukan raisons d'tre (alasan hidup) dalam komitmennya untuk isu-isu asli pada ideologinya dan energi untuk mengubah dunia menjadi tempat yang lebih baik untuk hidup. Panjang umur gerakan modern!

\section{PEMBAHASAN}

Berikut ini adalah hal-hal yang tidak boleh dilanggar oleh Michael selama bekerja pada Vignelli. Michael Bierut sepuluh tahun lamanya bekerja dibawah bimbingan Massimo Vignelli pada dalam Vignelli Associates. Hal yang tidak boleh dilanggar adalah: (1) hanya menggunakan typeface: Helvetica, Futura, Times, Futura, Garamond no.3 dan Bodoni; (2) jangan menggunakan lebih dari dua typeface untuk setiap proyek desain; (3) jangan menggunakan lebih dari tiga point size type face untuk setiap proyek desain; (4) selalu menggunakan modular grid untuk layout setiap proyek desain termasuk kartu nama, kop surat dan amplop; dan (5) selalu memakai referensi visual dari Josef MullerBrokmann atau Armin Hoffman.
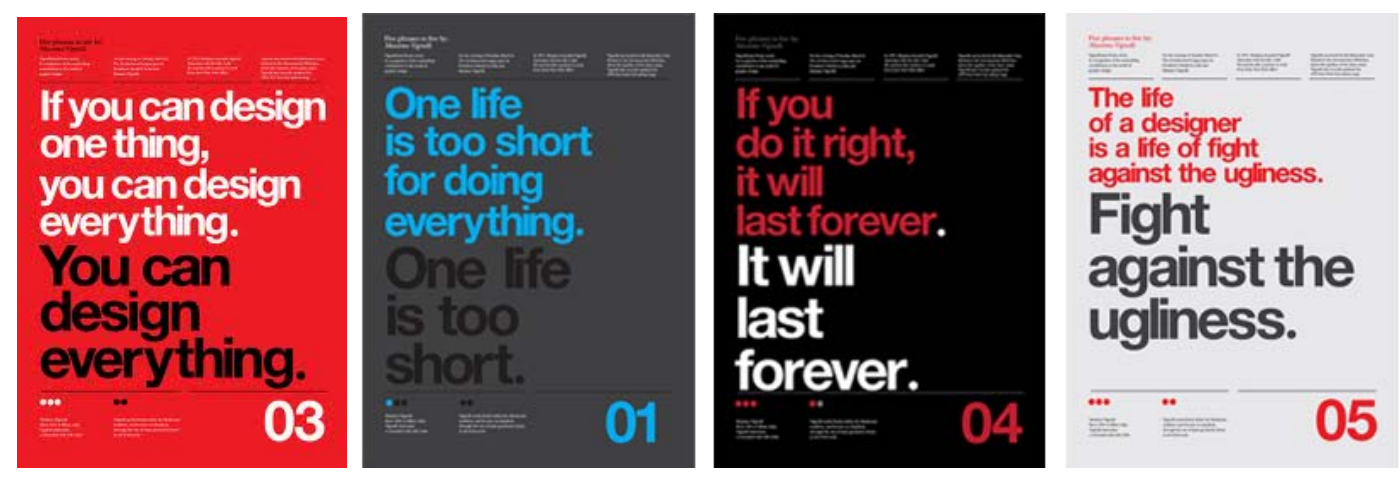

Gambar 1 Contoh-contoh karya Massimo Vignelli

Dalam Gambar 1, bisa dilihat bahwa semua jenis tulisan terlihat rapi dan teratur sesuai aturan main dari Vignelli Associates. Keinginan untuk berontak sudah bermula sejak awal Michael Bierut masuk pada Vignelli Associates namun apa daya itu adalah pengalaman pertama Michael bekerja.

Sebenarnya Michael mencintai aliran jenis Wolfgang Wingart hingga Pushpin Studio semenjak dia sekolah. Portofolio Michael saat sekolah desain adalah cerminan dari kecintaannya pada aliran tersebut dan menyebabkan Michael seperti orang yang memiliki keperibadian ganda. serta pertemuannya dengan Tibor Kalman memberikan angin segar dan mengembalikan jati diri yang sesungguhnya). 


\section{Pendapat Michael Bierut terhadap Pemilihan Typeface}

Hal ini terjadi setelah Michael Bierut keluar dari Vignelli Associates.

\section{Karena Typeface itu Berlaku}

Michael Bierut mengatakan walaupun ia sudah menentukan typeface yang begitu eksotis untuk sebuah identitas visual dan berjalan sangat baik untuk headline maupun bodytext. Tapi ada halhal tertentu yang dia tidak bisa lepas ketika memerlukan tipe dengan point size yang begitu kecil, disitulah gunanya Franklin Gothic menurutnya. Michael Bierut juga menganjurkan kita untuk berhatihati dalam memilih typeface karena beberapa typeface berjalan terlalu baik, contohnya adalah Frutiger yang sangat lekat dengan signage rumah sakit dan bandara. Michael Bierut mengatakan seakan-akan setiap melihat Frutiger, dia sedang mengalami tumor otak atau ketakutan terlambat menuju bandara.
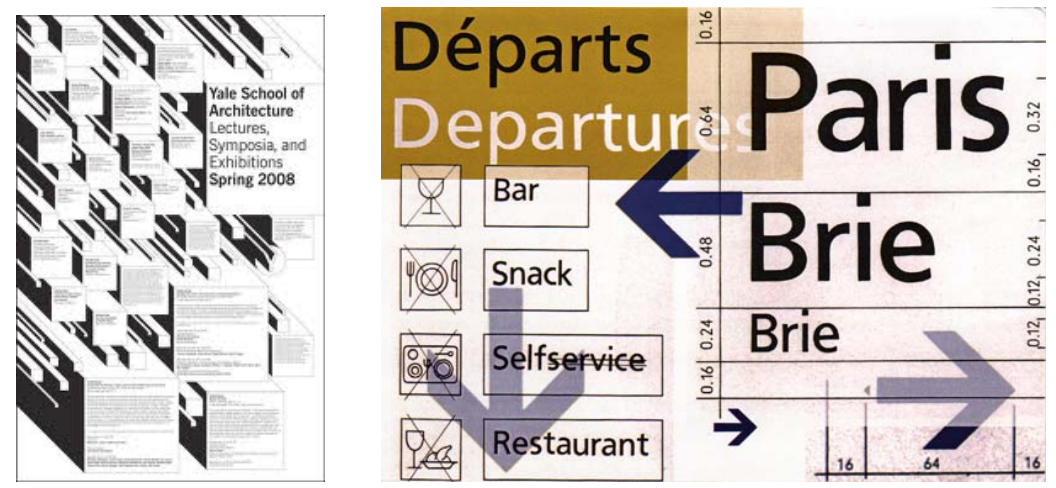

Gambar 2 Contoh typeface yang dilakukan Beirut

\section{Persamaan Sejarah}

Persamaan sejarah antara berdirinya perusahaan dan sejak mulainya typeface itu diciptakan dapat merupakan alasan yang kuat dalam pemilihan typeface tersebut. Karena aura typeface itu menjadi begitu kuat. Contohnya: Michael Bierut tidak pernah menyukai typeface Eurostile ciptaan Aldo Novarese, tetapi begitu typeface tersebut digunakan untuk judul buku Eero Saarinen terasa begitu tepat, karena keduanya berbagi ekspresi khas optimisme pasca perang tahun 1950.

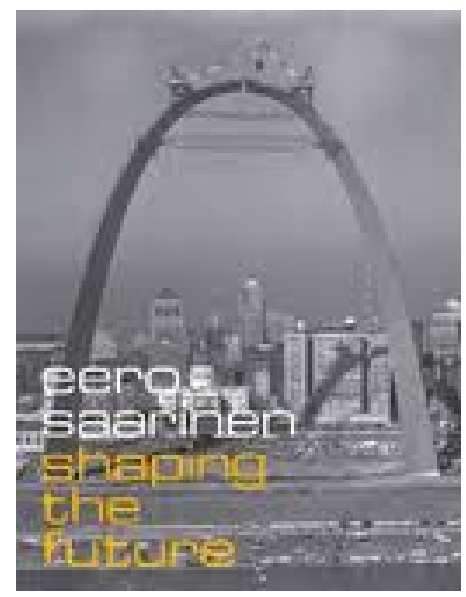

Gambar 3 Contoh typeface dan sejarah 


\section{Suka Nama Typeface}

Michael Bierut pernah suatu kali melihat proyek siswi desain grafis yang sedang merancang identitas perusahaan bernama "Tiffany". Michael Bierut secara pribadi tidak menyukai font yang dipilih siswi tersebut, dan dia mencoba bertanya dengan sopan mengapa siswi itu memilih typeface tersebut. “Oh!!!” jawab sang siswi dengan antusias "Itu adalah desain saya yang terbaik, saya memilih typeface yang bernama Tiffany”. Pada sisi lain, Bruce Mau membuat desain buku Spectacle untuk sang arsitek ternama David Rockwell, menggunakan typeface Rockwell. Menurut Michael Bierut itu adalah suatu hal yang lucu.

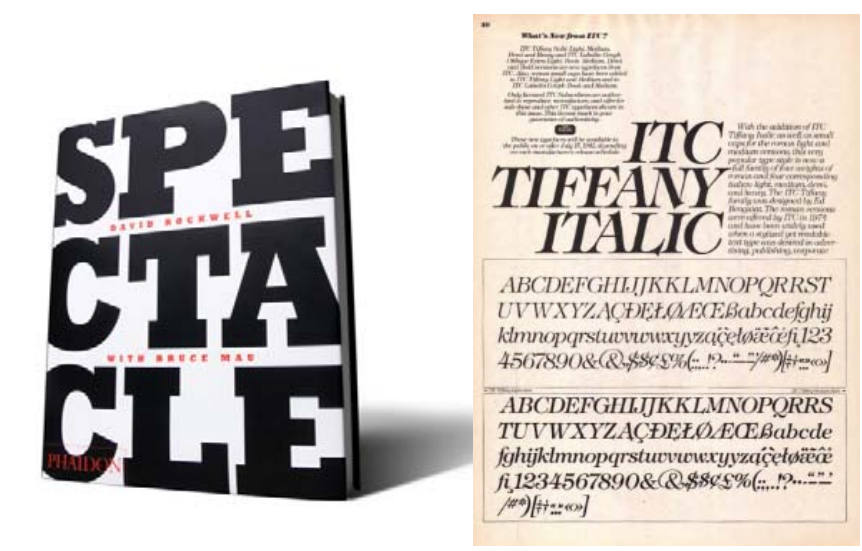

Gambar 4 Contoh typeface yang memiliki nama sesuai karakter typeface

\section{Desainer Typeface}

Pada suatu kesempatan Michael Bierut pernah mendapatkan klien yang mempunyai pemikiran arsitektural yang sangat kuat. Oleh sebab itu dia memilih Cehltenham yang bukan hanya cocok dengan proyek itu namun typeface tersebut didesain oleh Bertram Goodhue seorang arsitektur pada tahun 1896. Setelah itu, Michael Bierut membuat desain untuk program publikasi sekolah putri. Dia menggunakan typeface yang didesain seorang desainer perempuan yaitu: Zuzana Licko dan typefacenya secara kebetulan menggunakan nama perempuan juga yaitu: Mrs Eaves. Dalam kasus ini memang publik tidak akan menyadari cerita dibalik pemilihan font tersebut tapi Michael Bierut dan kliennya memiliki kenyamanan dan kepuasan tersendiri.

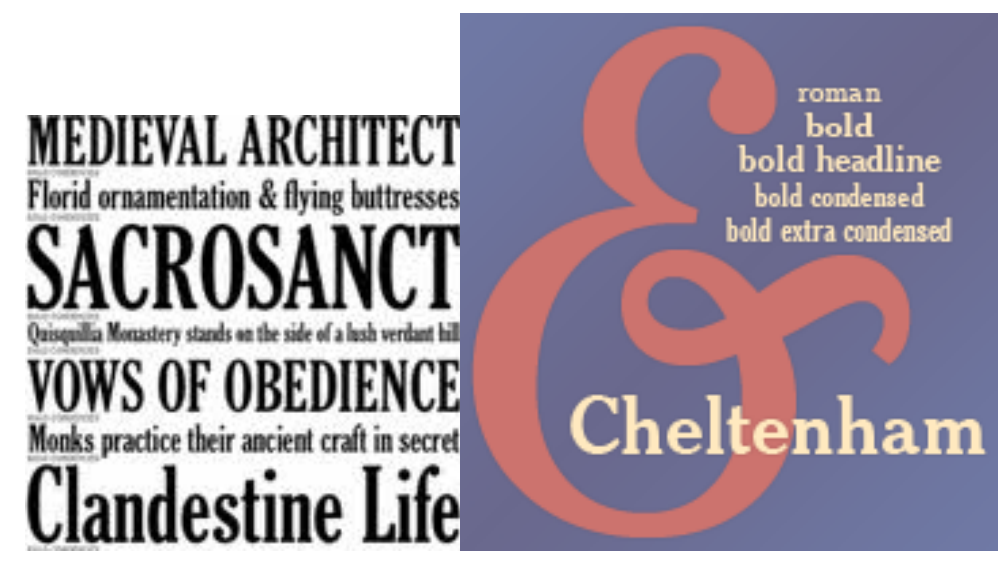

Gambar 5 Typeface yang didesain oleh desainer 


\section{Typeface Sudah Ada Sebelumnya}

"Terkadang typeface itu sudah ada sebelum kehadiran anda sebagai desainer di sana dan seakan kita hadir untuk mengenyahkan typeface itu" ujar Michael Bierut. "Kami menggunakan Baskerville dan Univers 65 pada semua materi kami, tetapi anda dibebaskan untuk membuat usulan alternatif typeface." Kata sang Klien. "Mengapa harus repot-repot?” jawab Michael Bierut. Ini seperti adegan di mana koki amatir diberi lobak, kantong terigu, kaki domba dan beberapa sirup maple dan menyuruh untuk membuat hidangan dari itu semua. Kadang-kadang sesuatu yang belum pernah kita gunakan sebelumnya akan membuatnya menjadi hal tersebut menjadi lebih menyenangkan.

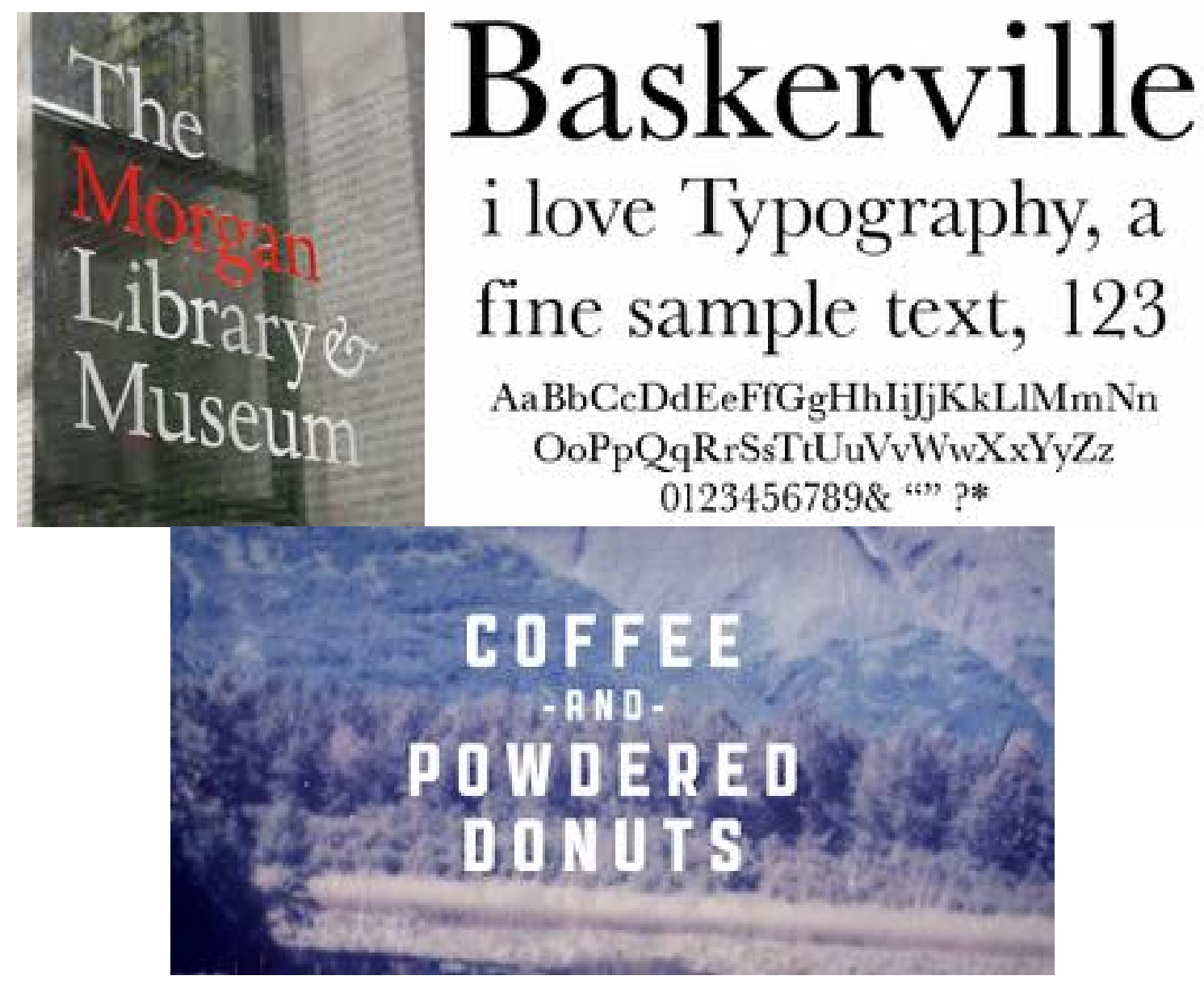

Gambar 6 Contoh typeface yang sudah ada sebelumnya

\section{Typeface Mengingatkan tentang Sesuatu}

Setiap kali Michael Bierut ingin membuat kata-kata yang terlihat to-the-point atau seperti sedang bercakap-cakap dan terlihat cerdas, Michael Bierut sering mempertimbangkan Futura, untuk huruf besar dan huruf kecilnya. Mengapa? Ini bukan karena Paulus Renner sang pencipta Futura, sosoknya terlihat to-the-point atau senang bercakap-cakap dan terlihat cerdas walau mungkin Paulus Renner seperti itu, tapi ini karena 45 tahun yang lalu, Helmut Krone memutuskan untuk menggunakan Futura dalam periklanan Doyle Dane Bernbach untuk Volkswagen, dan mereka masih menggunakan sampai hari ini. 


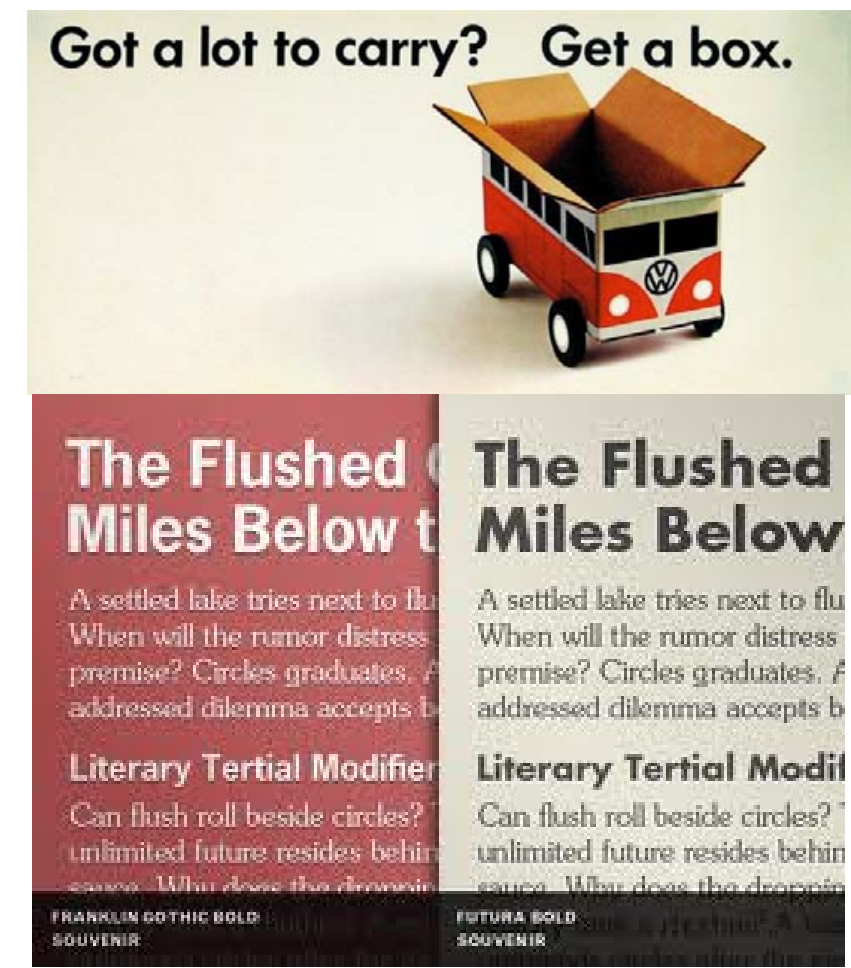

Gambar 7 Typeface yang berhubungan dengan suatu hal

\section{Typeface Jelek}

Sekitar 10 tahun yang lalu, saya diminta untuk mendesain ulang logo untuk majalah New York. Logo tersebut adalah desain dari Milton Glaser yang memakai typeface Bookman Cabe Italic, typeface yang sangat kuno dan jelek. Tapi logo Glaser telah diganti sebelumnya oleh Peter Palazzo yang didasarkan pada Caslon Italic. Michael Bierut mengusulkan untuk kembali ke Caslon, dan Michael Bierut sangat ingat pernah mengatakan, "Bookman Cabe Italic, selalu akan terlihat jelek." Hari lain, Michael Bierut melihat sesuatu di kantor yang benar-benar tertangkap mata saya. Sebuah majalah New York yang didesain dengan Bookman Cabe Italic, dan tampak hebat. Jelek, tapi hebat.

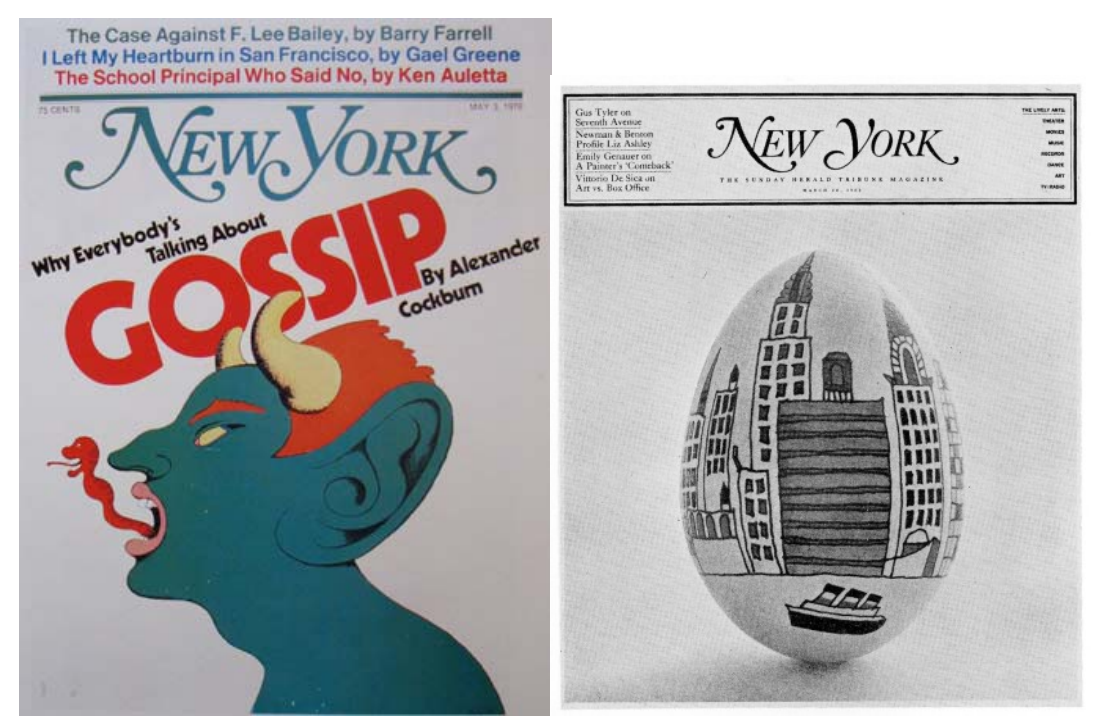

Gambar 8 Contoh typeface jelek tetapi hebat 


\section{Typeface Membosankan}

Tibor Kalman sangat terkesan dengan semua typeface yang membosankan. "Tidak! yang satu ini terlalu pintar, dan yang satu ini terlalu menarik," dia terus mengatakan ketika menunjukkan padanya font yang Michael Bierut usulkan untuk monograph. Apa saja namun memakai jenis huruf yang membosankan, Tibor merasa banyak mendapatkan ide-ide dari font tersebut. Dan akhirnya Tibor dan Bierut menetapkan Trade Gothic.

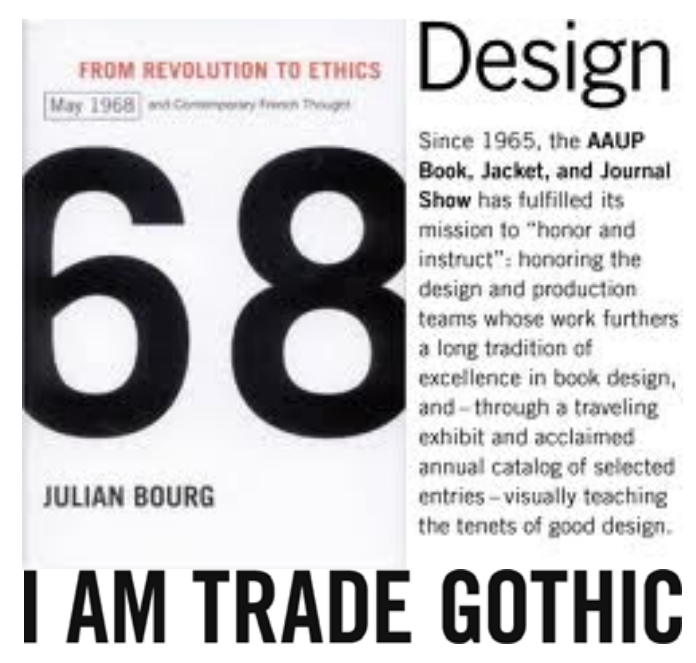

Gambar 9 Contoh typeface Trade Gothic

\section{Percaya pada Typeface}

Michael Bierut berkata, "Kadang-kadang saya berpikir bahwa Massimo Vignelli mungkin menggunakan tipografi terlalu banyak, bukannya terlalu sedikit. Seorang fundamentalis sejati membutuhkan pandangan dunia monoteistik: satu dunia, satu jenis huruf. Para desainer di Experimental Jetset telah membuktikannya dalam kasus Helvetica. Pasangan saya Abbott Miller memiliki periode kehidupan yang dia sebut Tahun Skala ketika ia menggunakan jenis huruf tertentu yang hampir secara eksklusif. Ketika waktunya tepat, hal tersebut dapat membuat type face tersebut semacam komitmen pribadi.”

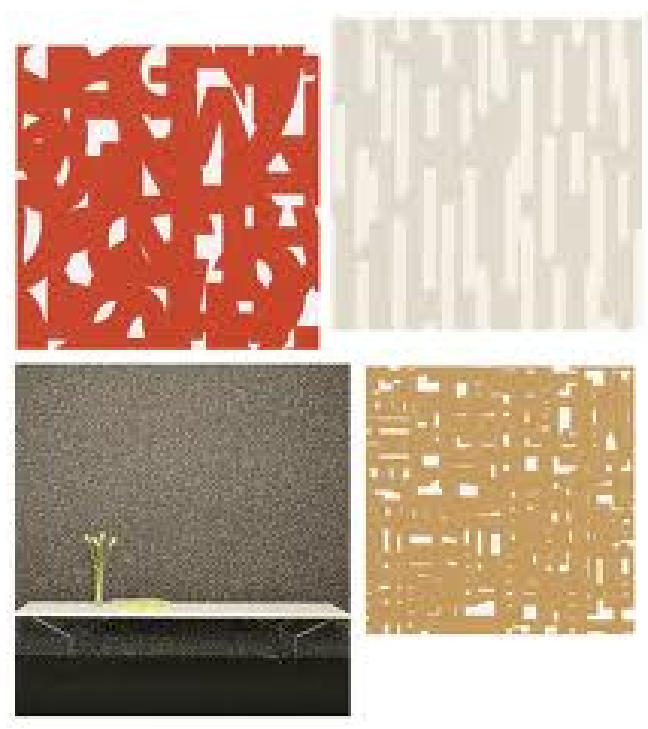

Gambar 10 Contoh penggabungan typeface 


\section{PENUTUP}

Pemilihan Typo bisa didasari banyak hal, seperti Vignelli lebih mementingkan kerapihan desain dengan menggunakan batasan-batasan seperti jumlah maksimum pemilihan typo, ukuran dan grid dasar sehingga menurutnya selaras dengan tujuan utamanya, tanpa neko-neko yang dianggap kuno dan membuahkan hasil yang monoton tidak menarik oleh Beirut. Terutama setelah Michael Bierut menggabungkan dua guru besar yang sangat mempengaruhinya dalam menempuh karirnya sebagai desainer grafis. Dia pernah bekerja pada Vignelli Associates selama 10 tahun, berkutat pada hal-hal yang sangat modernism. Setelah itu Michael bertemu dengan Tibor Kalman pada tahun 1996 untuk membuat monograph sebuah buku mengenai Tibor Kalman, otak Michael masih sangat terpengaruh dengan ajaran Vignelli. Lalu Tibor berkata pada Michael: "Lakukanlah semua yang pernah diajarkan oleh Vignelli, grid yang jernih, layout yang sangat sempurna, image yang diedit dengan sangat hati-hati, lalu...” Tibor tersenyum sejenak lalu melanjutkan, “...kita hancurkan sedikit aturan itu.” Hal tersebut yang mengubah Michael Beirut mejadi lebih bermain dan dianggap berontak dari aliran modernisme dan menjadi post-modernisme.

\section{DAFTAR PUSTAKA}

Aynsley, J. (2001). A century of graphic design. New York: Barron's Educational Series.

Bierut, M. (2007). Thirteen ways of looking at a typeface. Diakses 27 Juli 2011, dari http://observatory.designobserver.com/entry.html?entry=5497

Vignelli, M. (2006). Massimo Vignelli of vignelli associates. Diakses 27 Juli 2011 dari http://www.designboom.com/eng/interview/vignelli.html

Vignelli, M. (1991). Long live the modern movement. AIGA Journal of Graphic Design, vol. 9, no. 2, 1991. 